Available online on 15.05.2018 at http://jddtonline.info
Journal Of Drug Delivery and Therapeutics
Open Access to Pharmaceutical and Medical Research
commercial use, provided the original work is properly cited
comblisher and licensee JDDT, This is an Open Access article which permits unrestricted non-

Open

Access

Research Article

\title{
EVALUATION OF HYPOGLYCAEMIC, HYPOLIPIDAEMIC AND NON TOXIC EFFECT OF HYDRO-METHANOLIC EXTRACTS OF ZIZIPHUS MAURITIANA, ZIZIPHUS SPINA CHRISTI FRUIT AND GLIBENCLAMIDE ON ALLOXAN INDUCED DIABETIC RATS
}

\author{
Salisu M. Abubakar ${ }^{1}$, Sufyan A. Umar ${ }^{1}$, Idoko Alexander ${ }^{2 *}$, Nura Abubakar ${ }^{3}$, Mansurah A. Abdulazeez ${ }^{4}$ and \\ Muhammad S. Sule ${ }^{1}$ \\ ${ }^{1}$ Department of Biochemistry, Faculty of Basic Sciences, Bayero University, P.M.B. 3011, Kano, Nigeria \\ ${ }^{2}$ Department of Biochemistry, Faculty of Natural Sciences Caritas University Amorji - Nike, P.M.B. 01784, Enugu, Nigeria \\ ${ }^{3}$ Department of Biochemistry, Faculty of Sciences, Federal University Dutse, P.M.B. 7156, Jigawa State, Nigeria \\ ${ }^{4}$ Centre for Biotechnology Research, Bayero University, P.M.B. 3011, Kano, Nigeria
}

\section{ABSTRACT}

The use of plant products in the management of diabetes has gained ground in pharmacotherapy. It becomes imperative to evaluate the antidiabetic effects of fruit extracts of Ziziphus mauritiana (HMZM), Ziziphus spina christi (HMZS) and Glibenclamide on blood glucose, total protein, albumin and lipid profile in alloxan induced diabetic rats. 68 albino rats weighing $70-130 \mathrm{~g}$ were used in this study. 26 rats were used for acute toxicities of Ziziphus mauritiana and Ziziphus spina christi. 42 rats of 7 groups of 6 rats each were used to test antidiabetic effects of Ziziphus mauritiana and Ziziphus spina christi plant extracts. Group 1 served as the negative control, groups 2-7 were intraperitoneally administered $360 \mathrm{mg} / \mathrm{kg}$ of alloxan in normal saline respectively. Group 2 served as positive control, groups 3 and 4; 5 and 6 were respectively administered daily dose of 200 and 400mg/kg of HMZM and HMZS, group 7 was administered $0.21 \mathrm{mg} / \mathrm{kg}$ of glibenclamide. Results showed Ziziphus mauritiana and Ziziphus spina christi non toxic at dose of $5000 \mathrm{mg} / \mathrm{kg}$. 48 hours after alloxan administration, blood glucose levels were found to be significantly higher $(\mathrm{P}<0.05)$ in groups 2-7 compared to group 1 , thus confirming induction of diabetes. In groups $3-7$, on $7^{\text {th }}$ and $14^{\text {th }}$ days of administration of extracts and Glibenclamide, there was a significantly lower $(\mathrm{p}<0.05)$ serum glucose, triacylglycerol, High density Lipoprotein, Low density lipoprotein and significantly higher $(\mathrm{P}>0.05)$ serum level of total protein and albumin compared to group 2 . The results obtained showed a significantly lower $(\mathrm{P}<0.05)$ serum level of glucose. The effects of HMZM and HMZS fruit extracts on blood glucose, total protein, albumin and lipid profile was dose dependent. Conclusively, this study has demonstrated the antidiabetic effects of HMZM and HMZS with HMZS having a more pronounced effect on Blood glucose and lipid profile.

Keywords: Antidiabetic, Blood glucose, lipid profile, Glibenclamide, Ziziphus mauritiana, Ziziphus spina Christi.

Article Info: Received 08 Feb, 2018; Review Completed 25 April 2018; Accepted 29 April 2018; Available online 15 May 2018

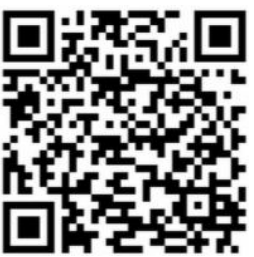

Cite this article as:

Abubakar SM, Umar SA, Alexander I, Abubakar N, Abdulazeez MA, Sule MS, Evaluation of hypoglycaemic, hypolipidaemic and non toxic effect of hydro-methanolic extracts of Ziziphus mauritiana, Ziziphus spina christi fruit and glibenclamide on alloxan induced diabetic rats, Journal of Drug Delivery and Therapeutics. 2018; $8(3): 82-92$

DOI: http://dx.doi.org/10.22270/jddt.v8i3.1711

\section{*Address for Correspondence:}

Idoko Alexander, Department of Biochemistry, Faculty of Natural Sciences Caritas University Amorji - Nike, P.M.B. 01784, Enugu, Nigeria

Conflict of Interests: Authors have declared that no competing interests exist. 


\section{INTRODUCTION}

Diabetes may be defined as a group of diseases resulting from insufficient or no insulin production or the combination of both ${ }^{1}$. Diabetes mellitus as a disease is ranked the 7 th killer disease in the world ${ }^{2}$. The International Diabetes Federation stated that about 366 million people are living with diabetes and this figure is projected to increase to 552 million by the year $2030^{3} .4$ stated that according to $\mathrm{WHO}$, the number of diabetic patients estimated would increase to at least 300 million by 2025 . The important regulatory role of insulin on glucose and lipid metabolism cannot be over emphasized. Thus, defect in hormonal insulin production is not unconnected to the unset of diabetes mellitus, which is associated with pronounced abnormality of lipoprotein metabolism, leading to hyperlipidaemia. Altered lipoprotein metabolism may be as a result of increase in production, decreased in absorption and maybe when the composition of lipoproteins changed, which in turn result in hyperlipaedemia in diabetes 5 . According to Clinical Practice Guidelines Expert Committee 2013, individuals who have history of or are suffering from certain diseases, such as genetic syndrome e.g. down syndrome, turner syndrome etc, pancreatic diseases e.g. cancer, cystic fibrosis, pancreatitis etc, Viral infections e.g cytomegalovirus etc, and endocrine diseases e.g. acromegaly, hyperthyroid etc, are likely to have diabetes. Diabetes may also result from the use of certain drugs such as thiazides, used to treat high blood pressure, Glucocorticoids drugs, such as cortisone, statins, used to treat high cholesterol level, drugs used to treat certain mental problems and epilepsy ${ }^{6}$. Experts have classified diabetes into three major types, which include type1, insulin deficiency, type 2 , insulin resistance and gestational diabetes results from insulin blocking hormone during pregnancy. Other forms of diabetes include; Maturity Onset Diabetes of the Young (MODY), a rare form of diabetes that generally occurs before the age of 25 in individuals of normal weight and Latent Autoimmune Diabetes of Adults (LADA), which occurs in adults between 30 to 50 years where there is a rapid dependence on insulin due to the slow and progressive destruction of the beta cells of the pancreas by the presence of antibodies ${ }^{7}$. General symtoms of diabetes include; slow healing wounds, fatigue, blurry vision, excessive thirst and hunger, frequent urination and itchy and scaly skin ${ }^{1}$.

Hyperlipidaemia has been found to be associated with the alteration of lipid and lipoproteins metabolism in the onset of diabetes mellitus ${ }^{5}$. Several researches have reported the positive correlation of metabolic disorders in lipid and lipoproteins metabolism in individuals suffering from diabetes to arteriosclerosis ${ }^{8}$. Several factors are said to be likely responsible for diabetic dyslipidemia, which include; insulin effects on liver apoprotein production, regulation of lipoprotein lipase $(\mathrm{LpL})$, actions of cholesteryl ester transfer protein (CETP) and peripheral actions of insulin on adipose and muscle 9 . Another report reveals that individuals diabetics with cardiovascular heart disease, were shown to have high total cholesterol, high low density lipoprotein (LDL) and reduced high density lipoprotein (HDL) compared to those without cardiovascular disease $^{10}$. Hypertriacylglycerolemia, reduced HDL and ketoacidosis have been reported to found in poorly controlled type 1 diabetes ${ }^{11}$.

Hyperglycemia, a metabolic challenge is connected to insulin deficiency in type-1 diabetes and insulin resistance in type 2 diabetes. ${ }^{12}$ report that Hyperglycemia and hyperlipidemia blocks the InsulinInositol polyphosphate-5-phosphatase (Inpp5f) negative feedback loop and increase of Inpp5f in diabetes due to hyperglycemia and hyperlipidemia plays an important role in diabetic cardiomyopathy suggest that, increase of Inpp5f might be one of the key mediators of metabolic stress (hyperglycemia and hyperlipidemia), which is an induced insulin signaling deficiency.

Several researchers have reported volumes of work showing how plants and fruits have provided useful remedies as hypoglycemic and hypolipidemic agents owing to the presence of phytochemical and bioactive compounds in plants and fruits. ${ }^{13}$ reported the hypoglycemic and lipid lowering effects of aqueous fresh Leaf extract of Chromolaena odorata (linn) in albino wistar rats fed different concentrations of cholesterol enriched diet. Several medicinal plants have been reported to be useful in diabetes worldwide and have been used empirically as anti-diabetic and antihyperlipidemic remedies ${ }^{14}$. A survey revealed that a number of cyclopeptide and isoquinoline alkaloids, flavonoids, terpenoids and their glycosides have been found to occur in various amounts in most Ziziphus species $^{15}$. Various researches has been done to show the anti-diabetic effects Ziziphus species such as,Anti diabetic activity of Ziziphus mauritiana in streptozotocin induced Diabetic Rats and its comparison with some standard flavonoids by ${ }^{14}$, the comparative antihyperglycemic, antihyperlipidemic and antioxidant effects of Ziziphus spina christi and Ziziphus jujube in alloxan induced diabetic rats by ${ }^{16}$, while there is the need to validate the claims that Ziziphus mauritiana and Ziziphus spina christiare potent anti-diabetic agents, there is also the need to know which of the Ziziphus species has a more potent anti-diabetic effect. As a certified anti-diabetic drug, glibenclamide was used in this study based on the fact that based it has health benefits such as it having a fast onset of action, little to no effect on blood pressure and lower risk of gastrointestinal problems compared to chlopropamide (which was the original drug intended for this study but wasn't used because it has been banned) and other antidiabetic drugs such as metformin and miglitol ${ }^{17}$. The aim of this research is to compare the anti-diabetic efficacy of hydro-methanolic (50:50) of Ziziphus mauritiana (HMZM) and Ziziphus spina christi (HMZS) fruit extract with antidiabetic drug Glibenclamide.

\section{MATERIALS AND METHODS}

\section{Collection and Preparation of Plant Material}

Ziziphusmauritiana fruits were obtained dried from Rimi market, Kano state, Nigeria. The fruits were authenticated and given voucher number 
DPB/BUK/HIF/0408 at the Plant Biology Department, Faculty of Life Sciences, Bayero University Kano, Nigeria. The fruit extracts were prepared by crushing the mesocarps of Ziziphusmauritiana. The dried mesocarps were ground to powder using mortar and pestle. The powdered fruit mesocarp was soaked in a mixture of water and methanol respectively (50:50) and allowed to stay for 48 hours at room temperature after which they were filtered. After filtration, $100 \mathrm{ml}$ of the extracts was then taken and evaporated to dryness using a rotary evaporator at $80^{\circ} \mathrm{C}$. The evaporated extracts were then reconstituted with distilled water relative to the weight of the evaporated extracts.

\section{Experimental Animals}

Policy of Bayero University Kano on research involving laboratory animals was followed in this study. Fifty-six male albino rats were used in this study. The rats were kept in cages under standard conditions and were fed with pelletized growers feed. They were allowed to acclimatize for a week before commencement of the experiment.

\section{Experimental Design}

A total of twenty-six rats were used for testing the acute toxicity of the extract of Ziziphus mauritiana fruit while thirty rats were used for testing the antidiabetic effects of the extract in comparison with antidiabetic drug, glibenclamide. The rats were distributed into five (5) groups of six (6) rats each as follows:

Group 1 - Six (6) non-diabetic rats fed with normal feed (Negative control)

Group 2- Six (6) diabetic rats fed with normal feed (Positive control)

Group 3 - Six (6) diabetic rats administered with $200 \mathrm{mg} / \mathrm{kg}$ of the hydro methanolic extract of the fruit of Ziziphusmauritiana

Group 4- Six (6) diabetic rats administered with $400 \mathrm{mg} / \mathrm{kg}$ of the hydro methanolic extract of the fruit of Ziziphusmauritiana

Group 5- Six (6) diabetic rats administered with $0.21 \mathrm{mg} / \mathrm{kg}$ of glibenclamide

The blood glucose levels of the rats in all groups were determined before commencement of the experiment by use of a glucometer. Also, after treatment with alloxan, the blood glucose levels were determined to confirm that the rats (from groups 2-5) were diabetic, before oral administration of extracts and glibenclamide. Blood glucose levels were also determined on the $7^{\text {th }}$ day and on the $14^{\text {th }}$ day post extract and glibenclamide treatments.

On the $7^{\text {th }}$ and $14^{\text {th }}$ day, the animals were sacrificed (three rats per group on each day) by decapitation and blood was obtained to determine the blood glucose levels, serum protein, serum albumin and lipid profile of the rats.

\section{Induction of Diabetes}

A stock solution was prepared by dissolving $0.4 \mathrm{~g}$ of alloxan monohydrate in $4 \mathrm{ml}$ of normal saline. Normal saline was prepared by dissolving $0.95 \mathrm{~g}$ of salt in $100 \mathrm{ml}$ of distilled water ${ }^{18}$. Diabetes was induced by single intraperitoneal injection of alloxan monohydrate. The rats in group 2-7 were intraperitoneally administered with $360 \mathrm{mg} / \mathrm{kg}$ of alloxan in normal saline respectively.

\section{Acute Toxicity Study}

The acute toxicities of the hydro-methanolic fruit extracts of Ziziphusmauritiana were evaluated in two phases as described by ${ }^{19}$. In the $1^{\text {st }}$ phase doses of $10 \mathrm{mg} / \mathrm{kg}, 100 \mathrm{mg} / \mathrm{kg}$, and $100 \mathrm{mg} / \mathrm{kg}$ were administered to 3 rats each. In the absence of any mortality in the 1 st phase, higher doses of $1500 \mathrm{mg} / \mathrm{kg}, 2500 \mathrm{mg} / \mathrm{kg}$, $3500 \mathrm{mg} / \mathrm{kg}$ and $5000 \mathrm{mg} / \mathrm{kg}$ were then administered on 1 rat each.

\section{Determination of Biochemical Markers of Diabetes Mellitus}

Blood Glucose was determined by the method of ${ }^{20}$; Serum Total Protein was determined by biuret method ${ }^{21}$; serum total cholesterol was determined using the method of ${ }^{22}$; Serum Level of HDL and LDLCholesterol was carried out using the method of ${ }^{23}$; Serum Triacylglycerol was determined by the method of 22

Reagents: All reagents used for the analysis of glucose, lipid profile and albumin in this study are of analytical grade purchased as kits produced by Randox Laboratories Limited, United Kingdom.

\section{Statistical analysis}

The results obtained in all the experiments were expressed as mean \pm standard deviation. Statistical analysis was carried out by using one way ANOVA as in standard statistical software package of social science and a component of Graph Pad Instat3 Software version 3.05 by Graph Pad Inc. was used with significant difference measured at $(\mathrm{P}<0.05)^{24}$.

\section{RESULTS AND DISCUSSION}

\section{Results}

\section{Acute Toxicity}

The results of the acute toxicity of hydro-methanolic Ziziphusmauritiana(HMZM) extract is shown in table 1. In the $1^{\text {st }}$ phase, doses of $10 \mathrm{mg} / \mathrm{kg}, 100 \mathrm{mg} / \mathrm{kg}$, and $1000 \mathrm{mg} / \mathrm{kg}$ were administered to 3 rats each of which no mortality was observed. In the absence of mortality in the1st phase, higher doses of $1500 \mathrm{mg} / \mathrm{kg}, 2500 \mathrm{mg} / \mathrm{kg}$, $3500 \mathrm{mg} / \mathrm{kg}$ and $5000 \mathrm{mg} / \mathrm{kg}$ were then administered on 1 rat each of which no mortality was observed in the $2^{\text {nd }}$ phase of the experiment.

Table 1a: Acute Toxicity of Phase I hydro-methanolic fruit extract of Ziziphusmauritiana

\begin{tabular}{|c|c|}
\hline Doses (mg/kg) & Result of First Phase \\
\hline 10 & $0 / 3$ \\
\hline 100 & $0 / 3$ \\
\hline 1000 & $0 / 3$ \\
\hline
\end{tabular}


Table 1b: Phase II hydro -methanolic fruit extract of ziziphusmauritiana

\begin{tabular}{|c|c|}
\hline Doses $(\mathbf{m g} / \mathbf{k g})$ & Result of Second Phase \\
\hline 1500 & $0 / 1$ \\
\hline 2500 & $0 / 1$ \\
\hline 3500 & $0 / 1$ \\
\hline 5000 & $0 / 1$ \\
\hline
\end{tabular}

The results of the acute toxicity of hydro-methanolic Ziziphusspina christi(HMZS) extract is shown in table 2. In the $1^{\text {st }}$ phase, doses of $10 \mathrm{mg} / \mathrm{kg}, 100 \mathrm{mg} / \mathrm{kg}$, and $100 \mathrm{mg} / \mathrm{kg}$ were administered to 3 rats each of which no mortality was observed. In the absence of mortality in the1st phase, higher doses of $1500 \mathrm{mg} / \mathrm{kg}, 2500 \mathrm{mg} / \mathrm{kg}$, $3500 \mathrm{mg} / \mathrm{kg}$ and $5000 \mathrm{mg} / \mathrm{kg}$ were then administered on 1 rat each of which no mortality was observed in the $2^{\text {nd }}$ phase of the experiment.

Table 2a: Acute Toxicity of phase I hydro-methanolic fruit extract of Ziziphus spina christi

\begin{tabular}{|c|c|}
\hline Doses $\mathbf{( m g / k g )}$ & Result of First Phase (Mortality) \\
\hline 10 & $0 / 3$ \\
\hline 100 & $0 / 3$ \\
\hline 1000 & $0 / 3$ \\
\hline
\end{tabular}

Table 2b: phase II hydro-methanolic fruit extract of Ziziphus spina christi

\begin{tabular}{|c|c|}
\hline Doses (mg/kg) & Result of Second Phase (Mortality) \\
\hline 1500 & $0 / 1$ \\
\hline 2500 & $0 / 1$ \\
\hline 3500 & $0 / 1$ \\
\hline 5000 & $0 / 1$ \\
\hline
\end{tabular}

The result of the effects of HMZM and HMZS on blood glucose in diabetic rats is shown in Figure 1 below. All the experimental groups (groups 3, 4, 5 and 6) showed a similar pattern of time dependency in blood glucose reduction during the 14 days treatment. As at the first day of the experiment (immediately after diabetes induction) group 1 rats (negative control) had a significantly lower $(\mathrm{P}<0.05)$ blood glucose level compared to rats in group 2 (positive control), group 3 (200mg/kg HMZM), group 4 (400mg/kg HMZM), group 5 (200mg/kg HMZS), group 6 (400mg/kg HMZS), and group $7(0.2143 \mathrm{mg} / \mathrm{kg}$ of glibenclamide). However, no significant differences $(\mathrm{P}>0.05)$ were observed when blood glucose levels of rats in groups 2-7 were compared at day 1 . The significantly higher $(\mathrm{P}<0.05)$ level of blood glucose observed in groups 2-7 rats compared to group 1 confirms that the rats were diabetic.

The blood glucose levels as at the $7^{\text {th }}$ day of administration of HMZM and HMZS shows a significantly lower $(\mathrm{P}<0.05)$ level of blood glucose in all groups compared to rats in group 2 (table 3). Significant differences $(\mathrm{P}<0.05)$ were also observed when blood glucose of group 3 and group 4, group 5 and group 6 were compared. The groups having the lowest blood glucose level were group 1, group 7 and group 6 (table 3). Significant difference $(P<0.05)$ was observed in the blood glucose levels of all groups (1-7) when compared to one another. However, there were no significant differences $(\mathrm{P}>0.05)$ observed between rats in group 7 and group 6, group 3 and group 5 .

The blood glucose levels as at the $14^{\text {th }}$ day of administration of HMZM and HMZS shows a significantly lower $(\mathrm{P}<0.05)$ level of blood glucose of rats in groups 1, group 3, group 4, group 5, group 6 and group 7 compared to rats in group 2 with group 1 and group 7 rats having the lowest blood glucose level (table $3)$. Significant differences $(P<0.05)$ were observed when serum blood glucose level of rats in groups 3 and 4 , groups 5 and 6 were compared. With the exception of group 4 and group 5 of which no significant difference $(\mathrm{P}>0.05)$ was observed in their blood glucose levels, significant difference $(\mathrm{P}<0.05)$ was observed in the blood glucose levels of all groups when compared to one another. The decrease in blood glucose level was found to be dose dependent such that blood glucose level of rats decreased with a corresponding increase in the doses of HMZM and HMZS extracts respectively.

Table 3: Blood Glucose concentrations (mg/dl) determined $48 \mathrm{hrs}$ after alloxan diabetes induction, $7^{\text {th }}$ and $14^{\text {th }}$ day of HMZM and HMZS extracts and glibenclamide administration

\begin{tabular}{|l|l|l|l|}
\hline & 48hrs After Alloxan $^{\text {th }}$ day of Administration & 14 $^{\text {th }}$ dayof Administration \\
\hline GRP I & $59.17 \pm 10.74^{\mathrm{ab}}$ & $53.67 \pm 14.26^{\mathrm{a}}$ & $43.67 \pm 4.04^{\mathrm{b}}$ \\
\hline GRP 2 & $238.00 \pm 48.98^{\mathrm{a}}$ & $241.50 \pm 90.64$ & $205.00 \pm 4.58^{\mathrm{a}}$ \\
\hline GRP 3 & $287.83 \pm 111.65^{\mathrm{ab}}$ & $207.67 \pm 30.38^{\mathrm{a}}$ & $132.33 \pm 56.04^{\mathrm{b}}$ \\
\hline GRP 4 & $241.83 \pm 40.81^{\mathrm{ab}}$ & $162.50 \pm 36.65^{\mathrm{a}}$ & $78.67 \pm 15.01^{\mathrm{b}}$ \\
\hline GRP 5 & $299.50 \pm 31.82^{\mathrm{ab}}$ & $191.67 \pm 47.38^{\mathrm{a}}$ & $92.00 \pm 17.09^{\mathrm{b}}$ \\
\hline GRP 6 & $272.50 \pm 120.46^{\mathrm{ab}}$ & $123.00 \pm 27.61^{\mathrm{a}}$ & $70.67 \pm 8.50^{\mathrm{b}}$ \\
\hline GRP 7 & $323.50 \pm 132.80^{\mathrm{ab}}$ & $109.00 \pm 43.97^{\mathrm{a}}$ & $54.00 \pm 8.72^{\mathrm{b}}$ \\
\hline
\end{tabular}

Results are mean \pm standard deviation, Values in the same row bearing similar superscripts are significantly different at $\mathrm{P}<0.05$. $(n=6)$. Key: GRP1: Negative Control, GRP2: positive Control, GRP3: Test group, GRP4: Test group, GRP5: Test group5, GRP6: Test group6, GRP7: Test group7 


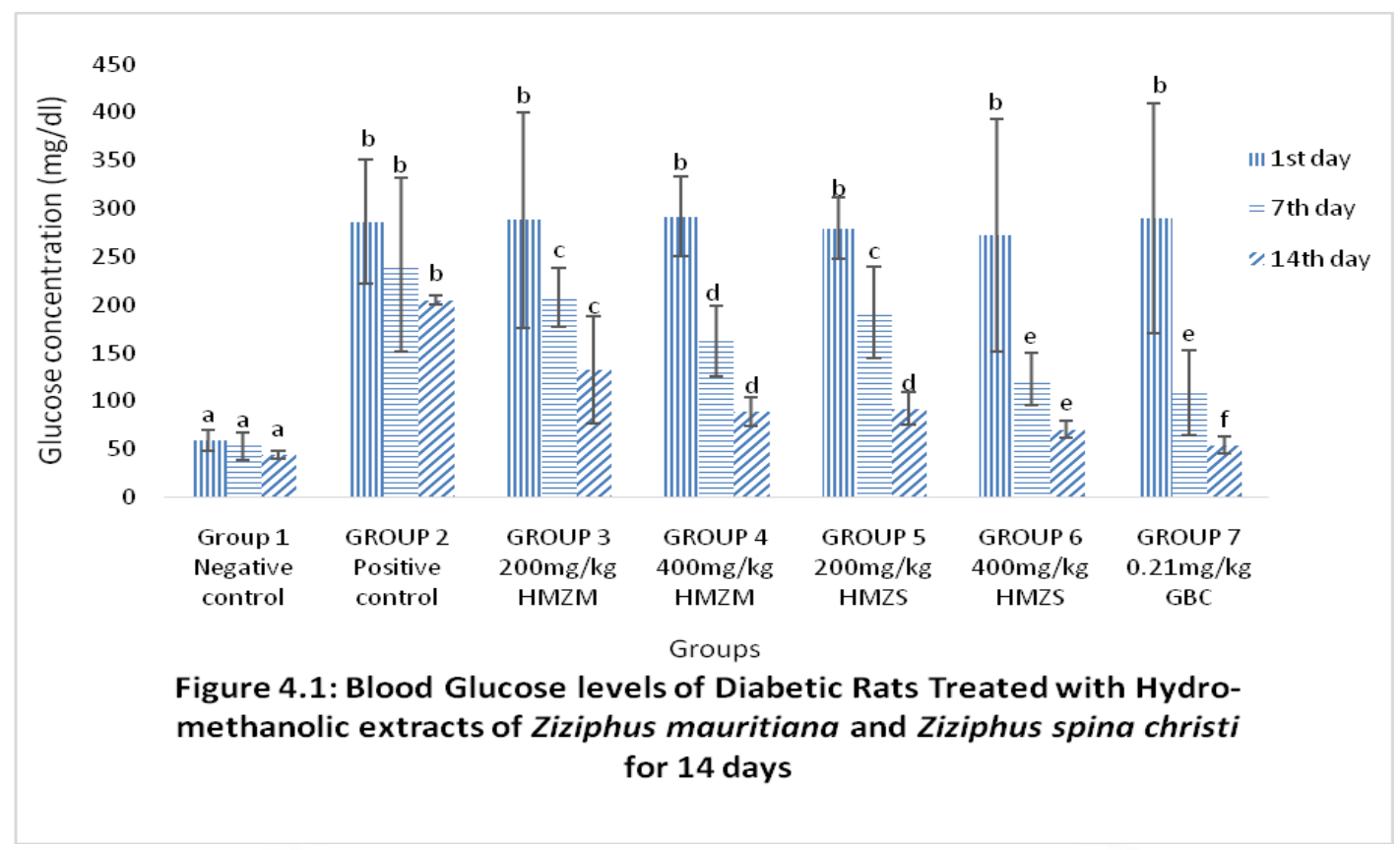

Results are expressed as Mean \pm Standard Deviation $(n=3)$.

Letters $\mathrm{a}, \mathrm{b}, \mathrm{c}, \mathrm{d}$, e and $\mathrm{f}$ indicates significant difference $(\mathrm{P}<0.05)$ when group 2 was compared with groups 1 , 3, 4, 5, 6 and 7, respectively. HMZM- HydromethanolicZiziphusmauritiana; HMZS- HydromethanolicZiziphus spina Christi; GBC- Glibenclamide

The results of the effects of hydro-methanolic fruit extracts of Ziziphusmauritiana and Ziziphus spina Christi on cholesterol, High Density Lipoprotein (HDL), Low Density Lipoprotein (LDL) and triacylglycerol are presented in Figures 2, 3, 4 and 5 respectively. The decrease in mean serum level of cholesterol, HDL-C, LDL-C and triglycerides was found to be dose dependent and it occurred with an increase in the doses of hydro methanolic Ziziphusmauritiana and Ziziphus spina christiextracts respectively.
As shown Figure 2, the results obtained on the $7^{\text {th }}$ day of administration of HMZM and HMZS show a significantly higher $(\mathrm{P}<0.05)$ level of serum triglycerides in group 2 rats (positive control), compared to rats in group 1 (negative control), group $3(200 \mathrm{mg} / \mathrm{kg}$ of HMZM), group $4(400 \mathrm{mg} / \mathrm{kg}$ of HMZM) group 5 (200mg/kg of HMZS), group 6 (400mg/kg of HMZS), and group $7 \quad(0.2143 \mathrm{mg} / \mathrm{kg}$ of glibenclamide $)$. Significant differences $(\mathrm{P}<0.05)$ were also observed when the serum triglyceride level of rats in group 3 and group 4, group 5 and group 6, were compared. Significant difference $(\mathrm{P}<0.05)$ was observed when the serum triacylglycerol levels of all groups (1-7) were compared with one another. However, there were no significant differences $(\mathrm{P}>0.05)$ in the serum triacylglycerol level of group 6 rats compared to group 7.

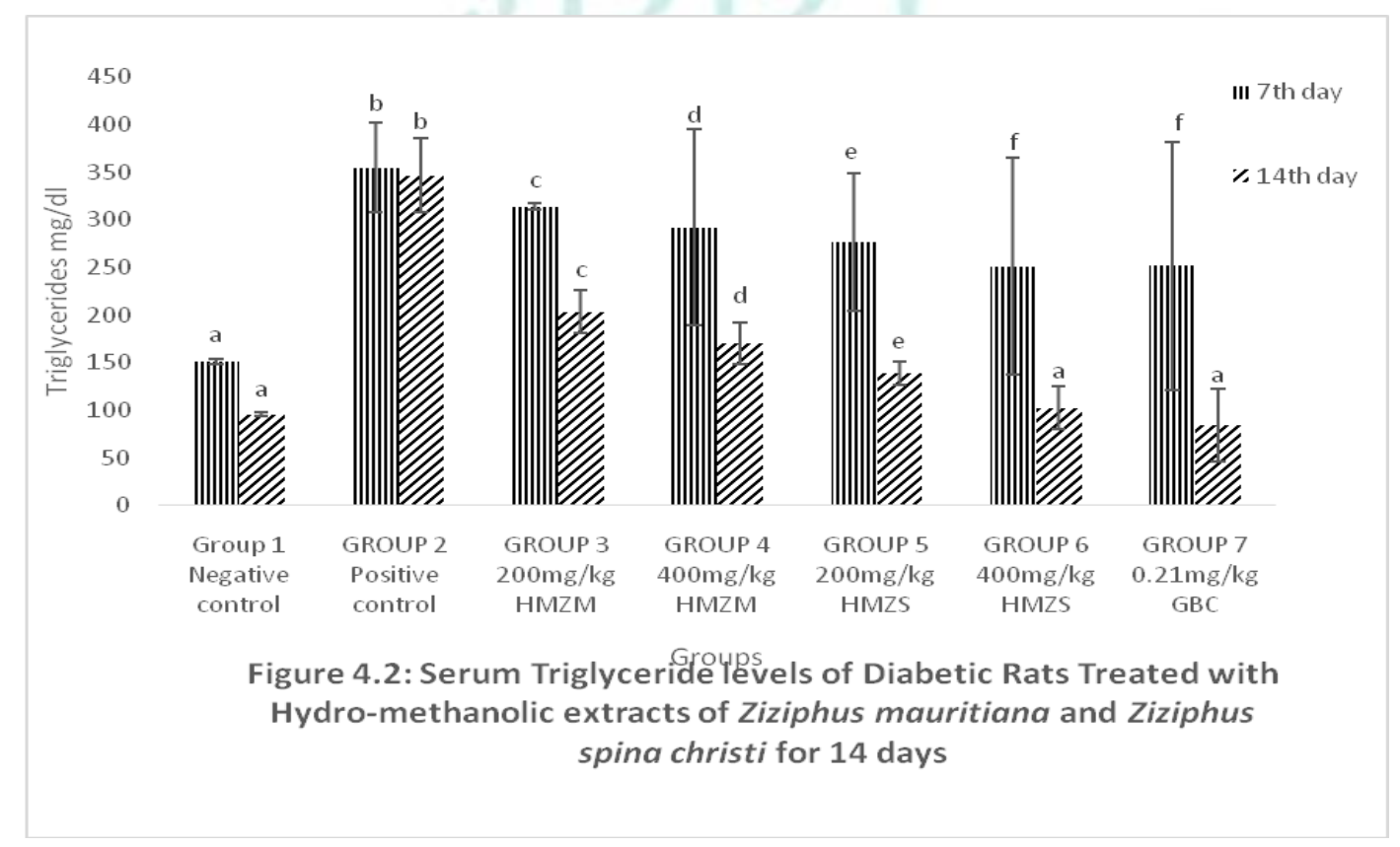

Results are expressed as Mean \pm Standard Deviation $(n=3)$. 
The results obtained as at the $14^{\text {th }}$ day of administration shows a significantly lower $(\mathrm{P}<0.05)$ level of serum triacylglycerol of rats in groups $1,3,4,5,6$ and 7 compared to rats in group 2, Significant differences $(\mathrm{P}<$ $0.05)$ were also observed when the serum triacylglycerol level of rats in groups 3 and 4, 5 and 6, were compared. Significant difference $(\mathrm{P}<0.05)$ was observed when the serum triacylglycerol levels of all groups (1-7) were compared with one another. However, no significant differences $(\mathrm{P}>0.05)$ were observed in the serum triglyceride levels of group 1, group 6 and group 7 rats which were having the lowest serum triacylglycerol level.

Letters a, b, c, d, e and ' $\mathrm{f}$ ' indicates significant difference $(\mathrm{P}<0.05)$ when group 2 was compared with groups 1, 3, 4, 5, 6 and 7, respectively. HMZMZiziphusmauritiana(Hydro-methanolic fruit extract); HMZS- Ziziphus spina christi(Hydro-methanolic fruit extract); GBC- Glibenclamide

Figure 3, shows the results obtained on the $7^{\text {th }}$ day of administration of HMZM and HMZS there was a significantly higher $(\mathrm{P}<0.05)$ level of serum HDL in group 2 rats (positive control), compared to rats in group 1 (negative control), group $3(200 \mathrm{mg} / \mathrm{kg}$ of HMZM), group $4(400 \mathrm{mg} / \mathrm{kg}$ of HMZM), group $5(200 \mathrm{mg} / \mathrm{kg}$ of HMZS), group $6(400 \mathrm{mg} / \mathrm{kg}$ of HMZS), and group 7 $(0.2143 \mathrm{mg} / \mathrm{kg}$ of Glibenclamide). Significant differences $(\mathrm{P}<0.05)$ were also observed when the serum HDL level of rats in groups 3 and 4, 5 and 6, were compared. Significant difference $(\mathrm{P}<0.05)$ was observed when the serum HDL-Cholesterol levels of all groups (1-7) were compared with one another. There was no significant difference $(\mathrm{P}>0.05)$ in the serum HDL level of group 4 compared to group 6.

The results obtained on the $14^{\text {th }}$ day of administration show further regression in the serum HDL of rats in groups 1, 3, 4, 5, 6 and 7 compared to rats in group 2.Significant differences $(\mathrm{P}<0.05)$ were also observed when the serum HDL level of rats in groups 3 and 4,5 and 6 , were compared. Significant difference $(P<0.05)$ was observed when the serum HDL-Cholesterol levels of all groups (1-7) were compared with one another. However, no significant difference $(\mathrm{P}>0.05)$ was observed when the serum HDL-Cholesterol level of groups 1, 4 and 7 rats were compared.

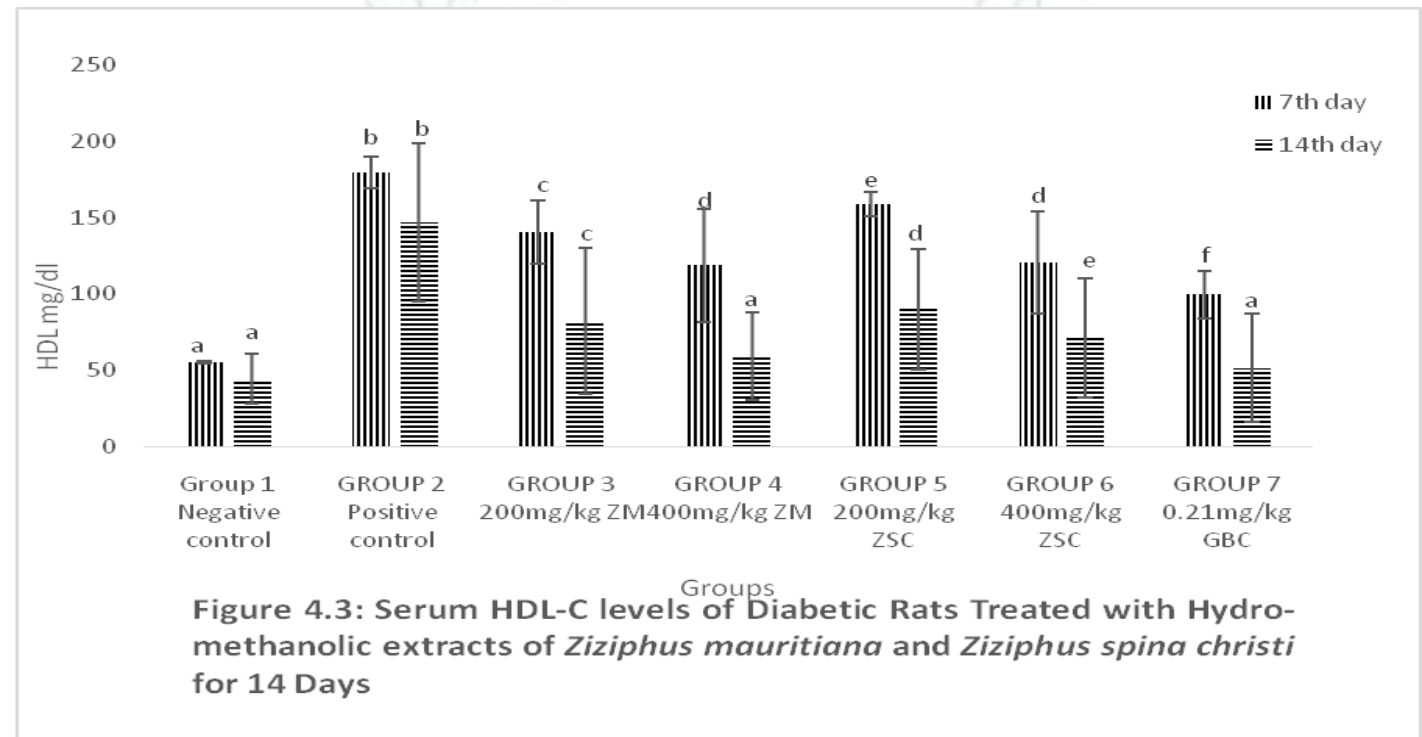

Results are expressed as Mean \pm Standard Deviation $(n=3)$; Letters $\mathrm{a}, \mathrm{b}, \mathrm{c}, \mathrm{d}$, e and ' $\mathrm{f}$ ' indicates significant difference $(\mathrm{P}<0.05)$ when group 2 was compared with groups 1, 3, 4, 5, 6 and 7, respectively; HMZM- Ziziphusmauritiana(Hydro-methanolic fruit extract); HMZS- Ziziphus spina christi(Hydro-methanolic fruit extract); GBC- Glibenclamide.

Figure 4 , shows the results obtained on the $7^{\text {th }}$ day of administration of HMZM and HMZS there was a significantly higher $(\mathrm{P}<0.05)$ level of serum cholesterol in group 2 rats (positive control), compared to rats in group 1 (negative control), group $3(200 \mathrm{mg} / \mathrm{kg}$ of HMZM), group $4(400 \mathrm{mg} / \mathrm{kg}$ of $\mathrm{HMZM})$, group 5 (200mg/kg of HMZS), group 6 (400mg/kg of HMZS), and group $7 \quad(0.2143 \mathrm{mg} / \mathrm{kg}$ of Glibenclamide). Significant differences $(\mathrm{P}<0.05)$ were also observed when the serum Cholesterol level of rats in group 3 and group 4, group 5 and group 6, were compared. Significant difference $(\mathrm{P}<0.05)$ was observed when the serum Cholesterol levels of all groups (1-7) were compared with one another. However, there was no significant difference $(\mathrm{P}>0.05)$ in the serum cholesterol level of group 6 compared to group 7 .

The results obtained as at the $14^{\text {th }}$ day of administration showed further regression in the serum cholesterol of rats in groups $1,3,4,5,6$ and 7 compared to rats in group 2. Significant differences $(\mathrm{P}<0.05)$ were also observed when the serum Cholesterol level of rats in groups 3 and 4, 5 and 6, were compared. Significant difference $(\mathrm{P}<0.05)$ was observed when the serum Cholesterol levels of all groups (1-7) were compared with one another. However no significant differences $(\mathrm{P}$ $>0.05)$ was observed when the serum cholesterol level of group 1 compared groups 6 and 7 rats, and 4 compared to group 5 rats. 


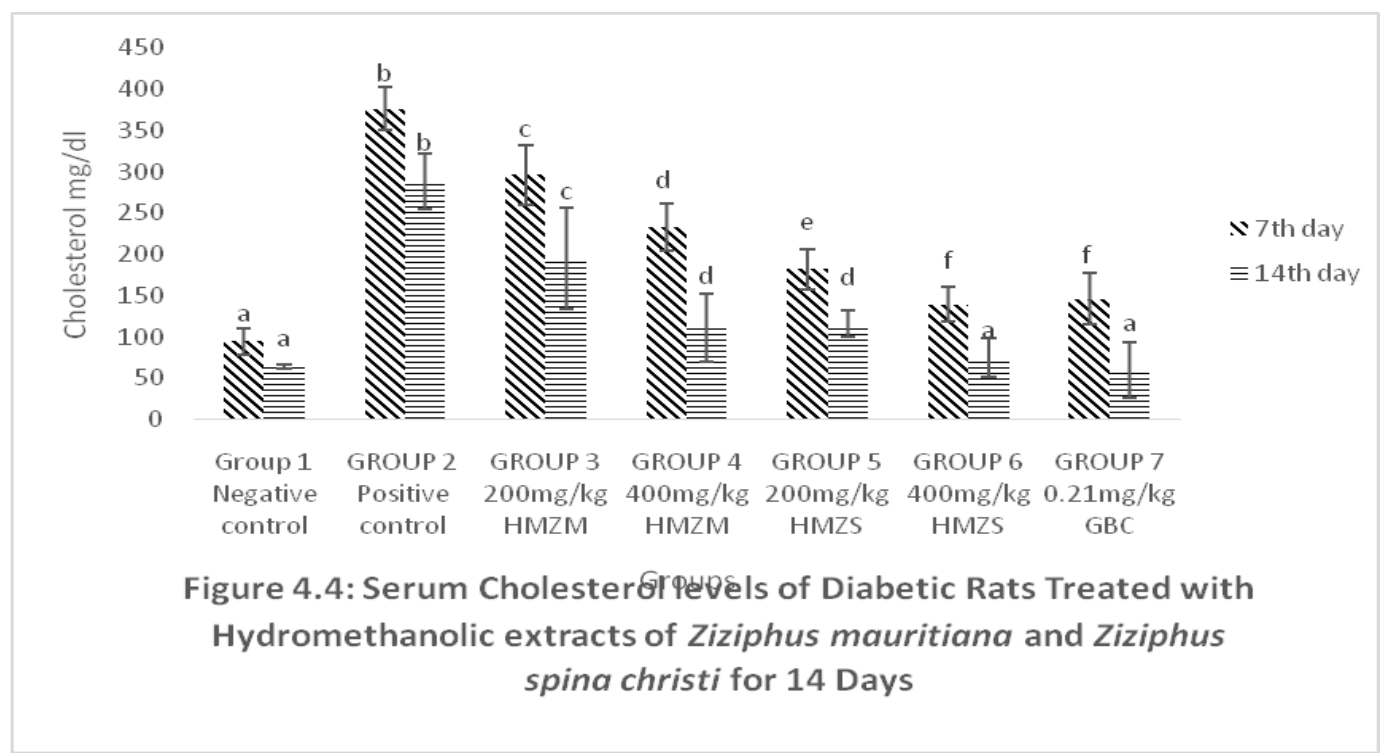

Results are expressed as Mean \pm Standard Deviation $(n=3)$; Letters a, b, c, d, e and ' $\mathrm{f}$ ' indicates significant difference $(\mathrm{P}<0.05)$ when group 2 was compared with groups 1, 3, 4, 5, 6 and 7, respectively; HMZM- Ziziphusmauritiana(Hydro-methanolic fruit extract); HMZS- Ziziphus spina christi(Hydro-methanolic fruit extract); GBC- Glibenclamide

Figure 5, shows the results obtained on the $7^{\text {th }}$ day of administration of HMZM and HMZS there was a significantly higher $(\mathrm{P}<0.05)$ level of serum LDL in group 2 rats (positive control), compared to rats in group 1 (negative control), group $3(200 \mathrm{mg} / \mathrm{kg}$ of HMZM), group $4(400 \mathrm{mg} / \mathrm{kg}$ of HMZM), group $5(200 \mathrm{mg} / \mathrm{kg}$ of HMZS), group $6(400 \mathrm{mg} / \mathrm{kg}$ of HMZS), and group 7 $(0.2143 \mathrm{mg} / \mathrm{kg}$ of glibenclamide).Significant differences $(\mathrm{P}<0.05)$ were also observed when the serum LDLCholesterol level of rats in groups 3 and 4, 5 and 6, were compared. Significant difference $(\mathrm{P}<0.05)$ was observed when the serum LDL-Cholesterol levels of all groups (1-7) were compared with one another. There were no significant differences $(\mathrm{P}>0.05)$ observed in the serum LDL level of group 4 compared to groups 5 and 6 compared to group 7 .

The results obtained as at the $14^{\text {th }}$ day of administration shows further regression in the serum LDL-Cholesterol of rats in groups 1, 3, 4, 5, 6 and 7 compared to rats in group 2.Significant differences $(\mathrm{P}<0.05)$ were also observed when the serum LDL level of rats in group 3 and 4, 5 and 6, were compared. Significant difference (P $<0.05)$ was observed when the serum LDL-Cholesterol levels of all groups (1-7) were compared with one another. However no significant difference $(\mathrm{P}>0.05)$ was observed when the serum LDL levels of groups 1 and 7 rats were compared.

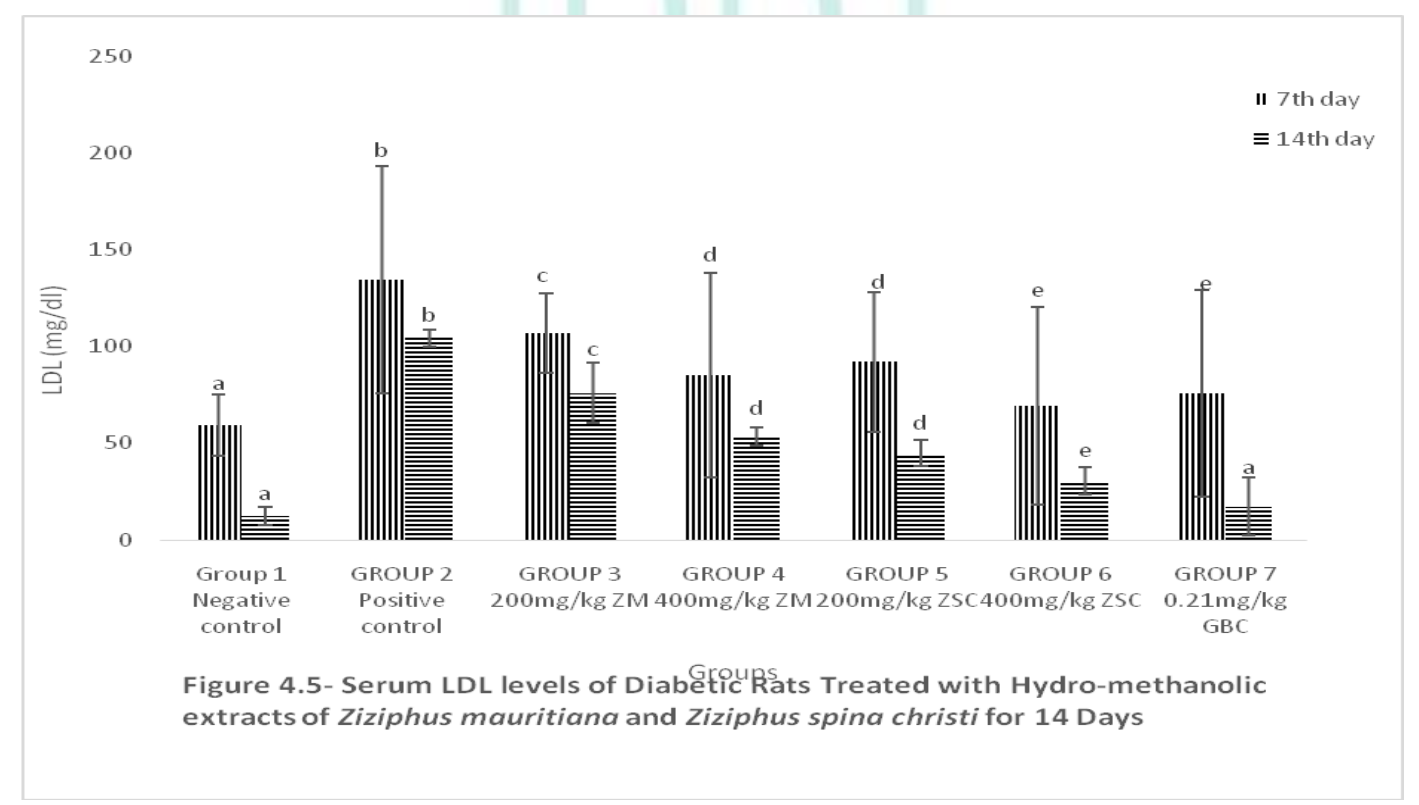

Results are expressed as Mean \pm Standard Deviation ( $n=3)$; Letters a, b, c, d, and e indicates significant difference $(\mathrm{P}<0.05)$ when group 2 was compared with groups 1, 3, 4, 5, 6 and 7, respectively; HMZM- Ziziphusmauritiana(Hydro-methanolic fruit extract); HMZS- Ziziphus spina christi(Hydro-methanolic fruit extract); GBC- Glibenclamide 
The results of the effects of hydro-methanolic fruit extracts of Ziziphusmauritiana and Ziziphus spina christion on total protein and albumin at the $7^{\text {th }}$ and $14^{\text {th }}$ day are presented in Figures 6 and 7 respectively. The increase in the mean serum level of total protein and albumin was found to be dose dependent and it occurred with an increase in the doses of hydro methanolic Ziziphusmauritiana and Ziziphus spina christiextracts respectively.

As shown in Figure 4.6, the results obtained on the $7^{\text {th }}$ day of administration of HMZM and HMZS show a significantly lower $(\mathrm{P}<0.05)$ level of serum total protein in group 2 rats (positive control), compared to rats in group 1 (negative control), group $3(200 \mathrm{mg} / \mathrm{kg}$ of HMZM), group $4(400 \mathrm{mg} / \mathrm{kg}$ of HMZM), group 5 (200mg/kg of HMZS), group 6 (400mg/kg of HMZS), and group $7(0.2143 \mathrm{mg} / \mathrm{kg}$ of glibenclamide).Significant differences $(\mathrm{P}<0.05)$ were also observed when the serum total protein level of rats in groups 3 and 4,5 and 6 , were compared. Significant difference $(\mathrm{P}<0.05)$ was observed when the serum total protein levels of all groups (1-7) were compared with one another. However, there was no significant difference $(\mathrm{P}>0.05)$ in the serum total protein level of group 4 compared to groups 5,6 and 7.

The results obtained as at the $14^{\text {th }}$ day of administration shows increase in the serum total protein of rats in groups 1, 3, 4, 5, 6 and 7 compared to rats in group 2.Significant differences $(\mathrm{P}<0.05)$ were also observed when the serum total protein level of rats in groups 3 and 4, 5 and 6, were compared. Significant difference $(\mathrm{P}<$ $0.05)$ was observed when the serum total protein levels of all groups (1-7) were compared with one another however no significant difference $(\mathrm{P}>0.05)$ was observed when the serum total protein level of groups 1 and 7 rats were compared.

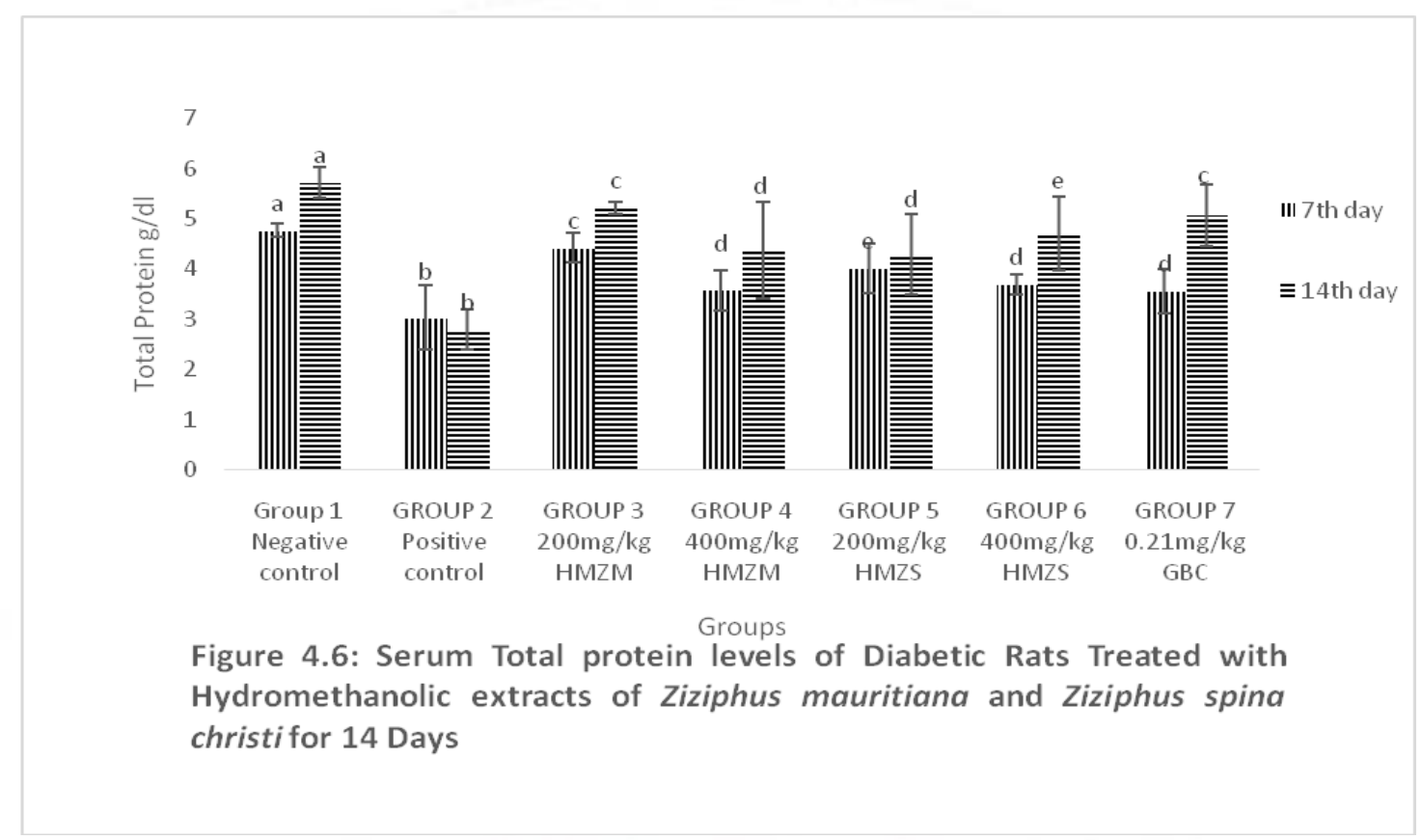

Results are expressed as Mean \pm Standard Deviation $(n=3)$; Letters a, b, c, d, and e indicates significant difference $(\mathrm{P}<0.05)$ when group 2 was compared with groups 1, 3, 4, 5, 6 and 7, respectively; HMZM- Ziziphusmauritiana(Hydro-methanolic fruit extract); HMZS- Ziziphus spina christi(Hydro-methanolic fruit extract); GBC- Glibenclamide

Figure 7 , shows the results obtained on the $7^{\text {th }}$ day of administration of HMZM and HMZS there was a significantly lower $(\mathrm{P}<0.05)$ level of serum albumin in group 2 rats (positive control) $(1.26 \mathrm{~g} / \mathrm{dl} \pm 0.19)$, compared to rats in group 1 (negative control), group 3 $(200 \mathrm{mg} / \mathrm{kg}$ of HMZM), group 4 (400mg/kg of HMZM), group $5(200 \mathrm{mg} / \mathrm{kg}$ of HMZS), group $6(400 \mathrm{mg} / \mathrm{kg}$ of HMZS), and group $7(0.2143 \mathrm{mg} / \mathrm{kg}$ of glibenclamide). Significant differences $(\mathrm{P}<0.05)$ were also observed when the serum albumin level of rats in group 3 and group 4, group 5 and group 6, were compared. Significant difference $(\mathrm{P}<0.05)$ was observed when the serum albumin levels of all groups (1-7) were compared with one another. However, there was no significant difference $(\mathrm{P}>0.05)$ when the serum albumin level of group 7 and group 5 rats, group 1 and group 6 rats, group 3 and group 4 rats were compared

The results obtained as at the $14^{\text {th }}$ day of administration shows increase in the serum albumin of rats in group 1 , group 3, group 4, group 5, group 6 and group 7 compared to rats in group 2. Significant differences $(\mathrm{P}<$ $0.05)$ were also observed when the serum albumin level of rats in group 3 and group 4, group 5 and group 6, were compared. Significant difference $(P<0.05)$ was observed when the serum albumin levels of all groups (1-7) were compared with one another.However no significant difference $(\mathrm{P}>0.05)$ was observed when the serum albumin level of group 3 and group 7 rats, group 4 and group 5 rats were compared. 


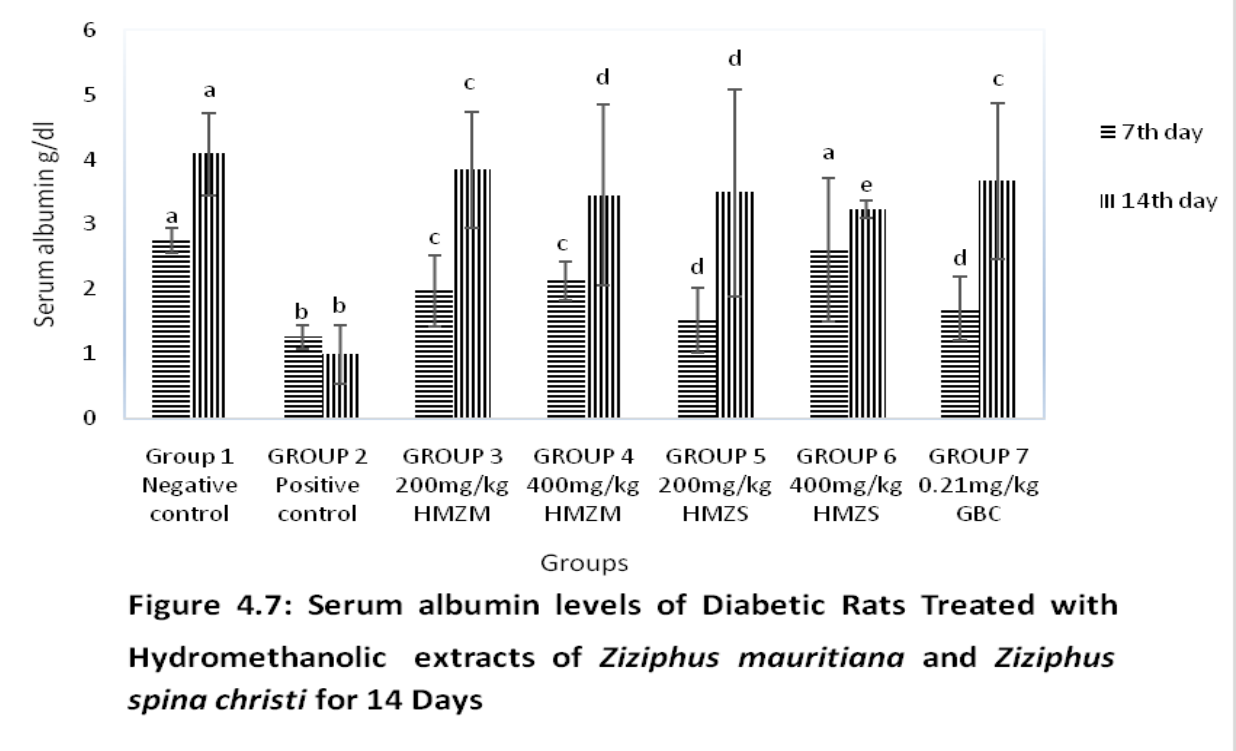

Results are expressed as Mean \pm Standard Deviation $(n=3)$; Letters a, b, c, d, and e indicates significant difference $(\mathrm{P}<0.05)$ when group 2 was compared with groups 1, 3, 4, 5, 6 and 7, respectively; HMZM-Ziziphusmauritiana(Hydro-methanolic fruit extract); HMZS- Ziziphus spina christi(Hydro-methanolic fruit extract); GBC- Glibenclamide

\section{DISCUSSION}

From the result of acute toxicity study (table 1 and 2) of Ziziphusmauritiana and Ziziphus spina Christi, no mortality was recorded in any of the experimental groups after oral administration of $5000 \mathrm{mg} / \mathrm{kg}$ of each extract, which proves these species harmless and non toxic and therefore safe to use. According to toxicity classification of ${ }^{25}$, any compound with oral $\mathrm{LD}_{50}$ of $5000 \mathrm{mg} / \mathrm{kg}$ or more should be considered as practically harmless. It has been argued that even if $\mathrm{LD}_{50}$ values could be measured exactly and reproducibly, the knowledge of its precise numerical value would barely be of practical importance, because an extrapolation from the experimental animals to man is hardly possible ${ }^{19}$. However, it serves a great purpose as a first pointer to the safety or toxic potential of a substance whose toxicity profile is not yet known.

Diabetes mellitus is a chronic disease characterized by high blood glucose level due to absolute or relative deficiency of circulating insulin level or insulin resistance. Though there are various types of hypoglycemic agent for treatment of diabetes, diabetic patients tend to consume natural products with antidiabetic activity to overcome side effects and toxicity of chemical drugs. Herbal antidiabetic drugs are used because they are effective and have low cost and less side effects ${ }^{26}$. The data (figure 1) obtained in this study with regards to the control values are in some ways similar to a study carried out by ${ }^{16}$ who studied the Antihyperglycemic, antihyperlipidemic and antioxidant effects of Ziziphus spina christi and Ziziphus jujube in alloxan induced diabetic rats with differences mainly in the lipid profile. The significantly higher $(\mathrm{P}<0.05)$ mean serum level of glucose in the diabetic control rats when compared to normal control rats may be due to possible damage to the pancreatic $\beta$ - islet cells by the effect of alloxan. Alloxan selectively destroys the islets of langerhans and decreases insulin production which results in diabetes ${ }^{27}$. Also, alloxan increases free radical production and cause pancreatic injury ${ }^{18}$. In otherwise, glibenclamide exerts hypoglycemic action by stimulation insulin secretion and inhibition of glucagon release. Previous studies carried out by ${ }^{28}$ on the phytochemistry of various Ziziphus species have shown that HMZM and HMZS contain saponins, tannins, carbohydrates and flavonoids. Thus, the regression in blood glucose level may be attributed to the presence of phytochemicals such as saponins and tannins which reduce blood glucose level by increasing insulin levels due to the stimulating effect of the extracts on the remaining $\beta$ cells in the pancreas after alloxan injection. The tannins in Ziziphus fruits have antioxidative effect. Oxidative stress is one of the important factors in tissue injury in diabetes mellitus ${ }^{29}$. These potent antioxidants may protect beta cells and increase insulin secretion in diabetic patients. Also, tannins may inhibit insulin degradation and improve glucose utilization by stimulation of GLUT4 (Glucose Transporter 4) protein content of the muscle ${ }^{30}$.

The significantly lower $(P<0.05)$ mean serum level of glucose as observed in the glibenclamide treated rats in comparison to Group 2 rats could be due to the fact that glibenclamide exerts its hypoglycemic effect by binding to and inhibiting the ATP sensitive potassium channels $\left(\mathrm{K}_{\mathrm{ATP}}\right)$ inhibitory regulatory subunit sulfonylurea receptor 1 (SUR1) in pancreatic beta cells. This inhibition causes cell membrane depolarization, opening voltage dependent calcium ion channels resulting in an increase in intracellular calcium in the beta cell and subsequent stimulation of insulin release ${ }^{31}$. Hence it can be inferred that both HMZM and HMZS can be used as safe potential natural functional food ingredient or 
therapeutic drug in the treatment of diabetes. In addition, they are effective in reducing both hyperglycemia and oxidative stress accompanying diabetes ${ }^{16}$ and although glibenclamide exerted more hypoglycemic and hypolipidemic effects compared to HMZM and HMZS, Ziziphus spina christiextract has more pronounced effects than Ziziphusmauritiana.

The significantly higher $(\mathrm{P}<0.05)$ serum lipids level observed in the groups 2-7 rats might be as a result of disturbance in the regulation of the activity of the enzyme, hormone sensitive lipase, by insulin due to its deficiency or absence, caused by the alloxan induced destruction of $\beta$ - islet cells ${ }^{31}$. Insulin deficiency in diabetes induces the synthesis of lipase which enhances lipolysis and increases the concentration of free fatty acids in plasma and liver. Glucagon level also increases in diabetes which enhances the release of fatty acids. Excess fatty acids in serum promote their conversion into cholesterol and TG with concomitant increase in $\mathrm{LDL}^{32}$. Moreover, insulin deficiency elevates LDL level and consequently the levels of cholesterol $^{33}$.

Several researchers have reported the use of plant fruits in reducing $\mathrm{LDL} \mathrm{TC}$ and $\mathrm{TG}$, exerting their lipid lowering effects ${ }^{34}$. The decrease in mean serum level of cholesterol, Low Density Lipoprotein (LDL) and triacylglycerol (TG) in this study, tend to support the claim of the use of plant fruits in the management of hypolipideamia resulting from diabetes. However, this may also be due to the presence of saponins which were also reported to have hypolipidemic effects by reducing total cholesterol, triglycerides, HDL and LDL cholesterol. This could be due to the fact that saponins form an insoluble complex with cholesterol, increase fecal lipid excretion ${ }^{35}$. They also increase liver LDL receptor activity and also decrease synthesis of triglycerides ${ }^{36}$. The obtained results are also in agreement with $^{37}$ that proved the antidiabetic effect of some Ziziphus species.
Hence it can be inferred that both hydro-methanolic fruit extracts of Ziziphusmauritiana and Ziziphus spina Christi are effective in reducing hyperlipidemia accompanying diabetes. However, Ziziphus spina Christi fruit extract has more pronounced effects than Ziziphusmauritiana.

The significantly lower $(\mathrm{P}<0.05)$ serum total protein level observed in the diabetic control rats might be as a result of increased breakdown of protein to generate ketogenic amino acids via gluconeogenesis for energy production. With insulin deficiency, the oxidation of branched chain amino acids in muscle and uptake of alanine by the liver are accelerated, resulting in increased gluconeogenesis and augmented protein catabolism $^{38}$. The results of the present study demonstrated that the treatment of diabetic rats with hydro-methanolic extracts of Ziziphusmauritiana and Ziziphus spina christi resulted to a noticeable elevation in the plasma total protein and albumin levels as compared with their normal levels. It has been established that insulin stimulates the incorporation of amino acids into proteins ${ }^{33}$.

\section{CONCLUSION}

In conclusion, this study has revealed that HMZM and HMZS could be used as safe potential natural functional food ingredient or therapeutic drug in the treatment of diabetes. In addition, they are effective in reducing both hyperlipidemia and hypoglycemia accompanying diabetes. Although the most effective dose which was $400 \mathrm{mg} / \mathrm{kg}$ of Ziziphus spina Christi extract had more pronounced antidiabetic effects than Ziziphusmauritiana, it was found to be less than that produced by the reference drug (glibenclamide). Hence it can be inferred that both hydro-methanolic fruit extracts of Ziziphusmauritiana and Ziziphus spina christican can be used as therapeutic drug in the treatment of diabetes.

7. Leslie D. and Valeri C. (2003) "LADA (Latent Autoimmune Diabetes in Adults)", Diabetes Voice, Vol. 48, p.14-16, International Diabetes Federation.

8. Manash P. Borgohain, Mangala Lahkar, Sahabuddin Ahmed, Liakat Chowdhury, Saurabh Kumar, Rajat Pant and Abhinav Choubey, Small Molecule Inhibiting Nuclear Factor-kB Ameliorates Oxidative Stress and Suppresses Renal Inflammation in Early Stage of Alloxan-Induced Diabetic Nephropathy in Rat, Basic \& Clinical Pharmacology \& Toxicology, 2017; 120(5):(442-449.

9. Ira J. Goldberg. Diabetic Dyslipidemia: Causes and Consequences. The Journal of Clinical Endocrinology \& Metabolism, 2001; 86(3): 965-971.

10. Alssema M, Dekker JM, Kuivenhoven JA, Nijpels G, Teerlink T, Scheffer PG, Diamant M, C. Stehouwer CDA, Bouter LM,Heine RJ, Elevated cholesteryl ester transfer protein concentration is associated with an increased risk for cardiovascular disease in women, but not in men, with Type 2 diabetes: the Hoorn Study, Diabetic Medicine, 2007; 24(2):117-123. 
11. Ginsberg HN. Diabetic dyslipidemia: basic mechanisms underlying the common hypertriglyceridemia and low HDL cholesterol levels. Diabetes. 1996; 45(Suppl 3):S27-S30.

12. Bai D. et al. Hyperglycemia and hyperlipidemia blunts the Insulin-Inpp5f negative feedback loop in the diabetic heart. Sci. Rep. 2016; 6, 22068; doi: 10.1038/srep22068.

13. Idoko A., Ikpe V. P. O, Rita O. N, Nelson N. O, Effiong JU, Alhassan A. J, Muhammad I. U, Abubakar N, Abubakar S. M Ugwudike P.O. Hypoglycemic and lipid lowering effect of aqueous fresh Leaf extract of Chromolaena odorata (linn) in albino wistar rats fed different concentrations of cholesterol enriched diet. Universal Journal of Pharmaceutical Research. 2018; 3(1):37-42.

14. Bhargava A and Rana A.C. Anti diabetic activity of Ziziphus mauritiana Lam. In streptozotocin induced Diabetic Rats and its comparison with some standard flavonoids. International Journal of Pharmaceutical Erudition 2014; 4(1):10-15.

15. Adzu, B., Amos, S., Amizan, M.B. and Gamaniel, K. Evaluation of the antidiarrhoeal effects of Ziziphus spina christi stem bark in rats. Acta. Trop. 2003; 87(2):245-250.

16. Hala M.H., Eman M.E., Aataa A.S. Antihyperglycemic,antihyperlipidemic and antioxidant effects of Ziziphus spina christi and Ziziphus jujube in alloxan induced diabetic rats. International Journal of Pharmacology 2006; 2(5):563-570.

17. Eurich M., Blackburn F.A., Majumdar D.F., Tsuyuki S.R., Varney R.T., Johnson J.A. "Benefits and harms of antidiabetic agents in patients with diabetes and heart failure: systematic review". BMJ (Clinical research ed.) 2007; 335(7618): p 497.

18. Szkudelski T. The mechanism of alloxan and streptozotocin action in B cells of the rat pancreas. Physiol. Res. 2001; 50:536-546.

19. Lorke D. A new approach to practical acute toxicity testing. Arch. Toxicol. 1983; 54:275-287.

20. Barham D and Trinder P. Colorimetric method for the determination of serum glucose. Clinical Pathology Analyst. 1972; 97:42.

21. Tietz N.W. (1995). Clinical Guide to Laboratory Tests, $3^{\text {rd }}$ edition. WB Saunders Cmpany. Philadephia. PA Pp. 518 519.

22. Trinder P. Cholesterol enzymatic end point manual. Ann. Clin. Biochem. 1969; 6:24-27.

23. Friedewald W.T., Levy R.I, Fredrickson D.S. Estimation of the concentration of low-density lipoprotein cholesterol in plasma, without use of the preparative ultracentrifuge. Clin Chem; 1972; 18:499-502.
24. Graph Pad Instat3 Software; 2000. Available:www.graphpad.com (Graph Pad Instat3, 2000)

25. Hodge A. and Sterner B. (2005) Toxicity Classes. In: Canadian Center for Occupational Health and Safety. Retrieved from http://www.ccohs.ca/oshanswers/chemicals/id50.htm.

26. Jahodar L. Plants with hypoglycemic effects. Ceskoslovenska Farmacie, 1993; 42(6):251-259.

27. Lenzen S. The Mechanisms of Alloxan- and Streptozotocininduced Diabetes. Diabetologia, 2008; 51(2):216-226.

28. Rabia N., Mir A.K., Kiran Y.K., Mushtaq A., Paras M., Barkat A., Mazhar M., and Muhammad, Z. A Review on Ziziphus as Antidiabetic. Journal of Applied Pharmaceutical Science; 2012; 2(3):177-179.

29. Baynes J.W. Role of oxidative stress in development of complications in diabetes. Diabetes 1991; 40:405-412.

30. Mohamadin A.M., Mariee A.D., El-Hefnawy H.M., and Fath E.M. Hypoglycemic activity of green tea extract in streptozotocin induced diabetic rats. Arab Journal of Laboratory Medicine, 2003; 29:397-400.

31. Tessier D. Glibenclamide vs gliclazide in type 2 diabetes of the elderly. Diabet Med. 1994; 11(10):974-980.

32. Sharma S.B., Hasir A., Prabhu K.H., Murthy, P.S., and Dev, G. Hypoglycemic and hypolipidemic effects of ethanolic extract of seeds of Eugenia jambolona in alloxan-induced diabetic rabbits. J. Ethnopharmacol. 2003; 85:201-206.

33. Al-Shamaony L., Al-Khaznaji S.M and Tway H.A.A. Hypoglycaemic effect of Artemisia herba alba II: Effect of valuable extract on some blood parameters, in diabetic animals. J. Ethnopharmacol. 194; 43:167-171.

34. Idoko A, Ikpe VPO, Nelson NO, Effiong JU, Alhassan AJ, Muhammad IU, Abubakar N, Abubakar SM. Effects of Lime Juice and Honey on Lipid Profile of Cholesterol Enriched Diet Fed Rat Model. Annual Research \& Review in Biology; 2017; 20(3):1-10.

35. Zhao H.L., Sim J.S., Shim S.H and Ha Y.W. Antiobese and Hyperlipidaemic effects of platycodin saponins in diet induced obese rats. Evidences for lipase inhibition and calorie intake restriction. Int. J. Obese, 2005; 29:983-990.

36. Yugarami, T., Tan, B.K.H., The, M and Das, N.P. Effects of polyphenolic natural Products on the lipid profile of rats fed high fat diets. Lipids, 1992; 27:181-186.

37. Cisse A., Ndiaye A., Lopez-Sall P., Seck F. and Faye B. Antidiabetic Activity of Ziziphusmauritiana. Dakar Medical, 2000; (45):105-107.

38. Felig P., Wahren J., Sherwin, R and Palaiologos G. Amino acid and protein metabolism in diabetes mellitus. Arch. Intern. Med. 1977; 137:507-513. 